\title{
2001: AN OVERVIEW
}

Eur. J. Histochem.

46: 105-106, 2002

(C) Luigi Ponzio e figlio - Editori in Pavia

\author{
Marco Biggiogera
}

Dipartimento di Biologia Animale, University of Pavia, Piazza Botta 10, 27100 Pavia, Italy

Among the papers published in the European Journal of Histochemistry in 2001, several deal with plant cells. Personally, as a cell biologist mainly working with animal cells, I have always been fascinated by plant cells: the images of those beautiful nuclei are not only something to look at and marvel at. In the past few years, important indications of cell structure and function have come from plant cytology and cytochemistry (see e.g. Medina et al., 2000). Along this line, Lingua and coworkers (2001) described the changes that occur after arbuscular mychorizal fungi colonization, which can induce a strong increase in metabolism. Nuclear changes can also be induced by pathogens, as in Licopersicon esculentum (Lingua et al., 2001).

In the same issue, we find other interesting papers: Balestrazzi et al. (2001) have studied the expression of DNA topoisomerase I in Daucus carota: the elucidation of the expression pattern of this gene is important in the evaluation of its physiological functions. In another paper, Bianciotto et al. (2001) studied the association of arbuscular mychorrizal fungi with rhizobacteria, which are commonly used as biopesticides and biofertilizers: the anchoring between fungi and bacteria occurs by means of extracellular polysaccharides. This could be of relevance for the production of inocula with a stable fugus-bacteria association.

Affinity cytochemistry was used by Baldan and coworkers (2001) to ascertain the presence of cellulose in algal cell walls.

In 2001, a number of papers were published in the field of Histochemistry in Pathology. Horita et al. (2001) studied the prognostic factors in breast cancer: in particular, the authors described the expression of PCNA, bcl-2, bax and wild-type p53 as important diagnostic markers at early stages of the disease. Two other papers from the same group (Ishida et al., 2001 and Iwasa et al., 2001) took into account a comparative study of two potentially invasive forms of intraepidermal squamous cell carcinoma and increased DNA instability in early stages of oral leukoplakia. As the above papers point out (and this is, once again, important and promising), histochemical tools are of great potential in diagnosis. During the last two decades, in fact, the histochemical goals have slowly turned from diagnosis confirmation to the early detection of diseaselinked cellular markers. The reviews published in 2001 also include a beautiful paper along the same lines: Steinbeck (2001), in his paper on pathologic mitosis and its significance in tumorigenesis, gives an up-to-date review of this topic, including cell division in tissue disorders, chromosome division figures and void cycle checkpoints.

Another interesting paper (Sedo et al., 2001) concerns cell membrane proteases; in particular, dipeptidyl peptidase IV in glioblastoma and astocytoma cultured cells. The authors suggest a positive correlation between the degree of transformation of cells and activity of this protease.

Among the technical improvements, I would like to cite the paper by Gallus et al. (2001) on the three-dimensionally-reconstructed distribution of FMRFamide immunopositive neurons in the ventral ganglion of Balanus.

There are still many more papers in the field of Basic Histochemistry that could be mentioned. Among them are the characterization of interstitial cells in pre- and post-natal development of sheep pineal gland (Redondo et al., 2001), the effect of light on lactate hydrogenase activity of the epididymis (Ponce et al., 2001), and the study of cell 
kinetics in a human skin equivalent, i.e. a bioengineered organ raised in vitro as a candidate for replacing damaged human skin (Casasco et al., 2001). In this category, we find also the paper by Artico et al. (2001) on the effect of interleukin 1 on the rat thymus, which describes the capability of this cytokine to affect the thymus even in aged rats. Finally, in the field of apoptosis, we find a paper on the cleavage of PARP-1 and the formation of strand breaks in DNA, describing how the p89 proteolytic fragment of poly(ADP-ribose) polymerase- 1 is resistant to protease degradation in the cytoplasm of apoptotic cells (Soldani et al., 2001). This finding increases the family of nuclear proteins which are extruded from the nucleus into the cytoplasm of apoptotic cells (Pellicciari et al., 2000) and could be involved in the genesis of autoimmune diseases, in the absence of a correct apoptotic clearance (Rovere et al., 2000).

The high quality of the papers published in 2001 is consistent with the important increase in the Impact Factor value of EJH which occurred in 2000: this is an apparent sign of a wider diffusion and an increasing impact of our Journal on the scientific community.

\section{REFERENCES}

Artico M., Cavallotti C., Iannetti G., and Cavallotti D.: Effect of Interleukin $1 \beta$ on rat thymus microenvironment. Eur. J. Histochem. 45, 357-366, 2001.

Baldan B., Andolfo P., Navazio L., Tolomio C., and Mariani P.: Cellulose in algal cell wall: an "in situ" localization. Eur. J. Histochem. 45, 51-56, 2001.

Balestrazzi A., Bernacchia G., Pitto L., Luccarini G., and Carbonera D.: Spatial expression of DNA topoisomerase I genes during cell proliferation in Daucus carota. Eur. J. Histochem. 45, 31-38, 2001

Bianciotto V., Andreotti S., Balestrini R., Bonfante P., and Perotto S.: Extracellular polysaccharides are involved in the attachment of Azospirillum brasilense and Rhizobium leguminosarum to arbuscular mycorrhizal structures. Eur. J. Histochem. 45, 39-49, 2001.

Casasco A., Casasco M., Icaro Cornaglia A., Zerbinati N., Mazzini G., and Calligaro A.: Cell kinetics in a model of artificial skin. An immunohistochemical and flow cytometric analysis. Eur. J. Histochem. 45, 125-130, 2001.

Gallus L., Diaspro A., Beltrame F., Fato M., and Tagliafierro G.: Three-dimensional computer-aided reconstruction of FMRFamide immunopositive neuron distribution in the ventral ganglion of the barnacle Balanus amphitrite (Cirripedia, Crustacea). Eur. J. Histochem. 45, 95-104, 2001.
Horita K., Yamaguchi A., Hirose K., Ishida M., Noriki S., Imamura Y., and Fukuda M.: Prognostic factors affecting disease-free survival rate following surgical resection of primary breast cancer. Eur. J. Histochem. 45, 73-84, 2001.

Ishida H., Kumakiri M., Ueda K., Lao L.M., Yanagihara M., Asamoto K., Imamura Y., Noriki S., and Fukuda M.: Comparative histochemical study of Bowen's disease and actinic keratosis: preserved normal basal cells in Bowen's disease. Eur. J. Histochem. 45, 177-190, 2001.

Iwasa M., Imamura Y., Noriki S., Nishi Y., Kato H., and Fukuda M.: Immunohistochemical detection of early-stage carcinogenesis of oral leukoplakia by increased DNA-instability and various malignancy markers. Eur. J. Histochem. 45, 333-346, 2001.

Lingua G., D’Agostino G., Fusconi A., and Berta G.: Nuclear changes in pathogen-infected tomato roots. Eur. J. Histochem. 45, 21-30, 2001.

Lingua G., Fusconi A., and Berta G.: The nucleus of differentiated root plant cells: modifications induced by arbuscular mycorrhizal fungi. Eur. J. Histochem. 45, 9-20, 2001.

Medina F.J., Cerdido A., and de Cárcer G.: The functional organization of the nucleolus in proliferating plant cells. Eur. J. Histochem. 44, 117-131, 2000.

Ponce R.H., Carriazo C.S., and Vermouth N.T.: Lactate dehydrogenase activity of rat epididymis and spermatozoa: Effect of constant light. Eur. J. Histochem. 45, 141-150, 2001.

Redondo E., Franco A., Masot A.J., and Regodón S.: Ultrastructural and immunocytochemical characterization of interstitial cells in pre- and postnatal de-veloping sheep pineal gland. Eur. J. Histochem. 45, 249-258, 2001.

Rovere P., Fazzini F., Sabbadini M.G., and Manfredi A.A.: Apoptosis and systemic autoimmunity: the dendritic cell connection. Eur. J. Histochem. 44, 229-236, 2000.

Sedo A., Malík R., Drbal K., Lisá V., Vlasicová K., and Mares V.: Dipeptidyl peptidase IV in two human glioma cell lines. Eur. J. Histochem. 45, 57-63, 2001.

Soldani C., Bottone M.G., Pellicciari C., and Scovassi A.I.: Twocolor fluorescence detection of Poly (ADP-Ribose) Polymerase1 (PARP-1) cleavage and DNA strand breaks in etoposideinduced apoptotic cells. Eur. J. Histochem. 45, 389-392, 2001.

Steinbeck R.G.: Pathologic mitoses and pathology of mitosis in tumorigenesis. Eur. J. Histochem. 45, 311-318, 2001. 